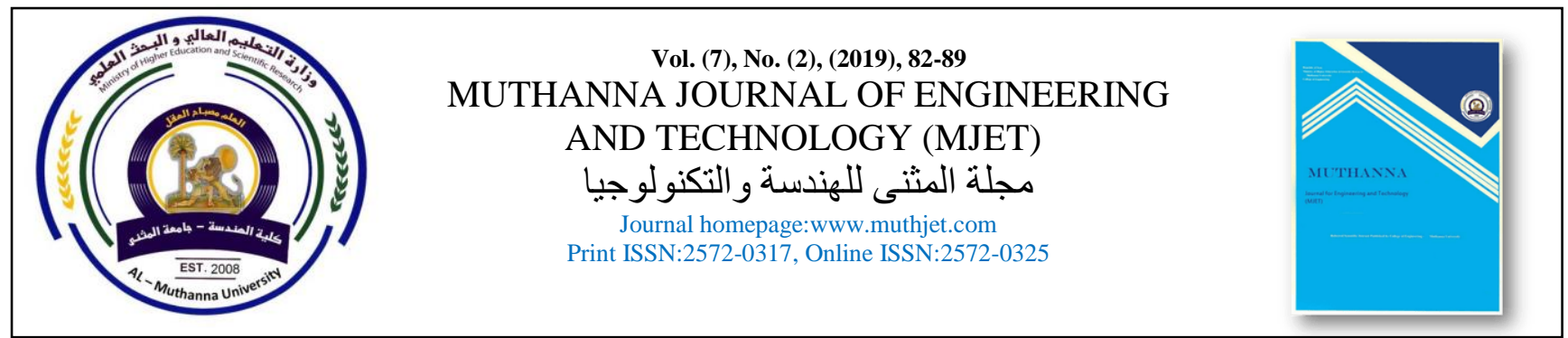

\title{
Efficiency Development of Light Weight High Strength Concrete by using Carbon Fibers.
}

\author{
Haider Araby Ibrahim ${ }^{1,}$, Mohammed Bally Mahdi², Basim Jabbar Abbas ${ }^{3}$ \\ 1,2,3 Civil Engineering Department, Al-Muthanna University, Samawa, IRAQ
}

\section{ARTICLE INFO}

Received: 05/09/2019

Accepted: 06/11/2019

\section{Keywords}

Light weight high strength concrete, Carbon Fibers, Silica Fume, compressive strength

\begin{abstract}
This study aims to progress brittleness of the high strength lightweight aggregate concrete (HSLWAC) by using Porcelinite stone as light weight aggregates and silica fume with water cement ratio 0.28 to give $41.34 \mathrm{MPa}$ compressive strength at 28-days and reinforced with carbon fibers. Fifteen mixtures using in this work with three various lengths of $(5 \mathrm{~mm}, 10 \mathrm{~mm}$, and $20 \mathrm{~mm})$, five mixes for every length with volume fractions $(0.25 \%, 0.5 \%, 1.0 \%, 1.5 \%$, and $2 \%$ ) of carbon fibers. The slump test, compression strength, flexural strength, splitting tensile strength, and modulus of elasticity were investigated to determine the mechanical properties of (HSLWAC). The density of reference (HSLWAC) that was get through the experimental work was $\left(1835 \mathrm{Kg} / \mathrm{m}^{3}\right)$ at $(28)$ days. The results shown that at general, the brittleness of (HSLWAC) improved with increased the content and length of carbon fibers, The optimum properties was for mix (L5) of $20 \mathrm{~mm}$ length and $2 \%$ of carbon fibers of $45.44 \mathrm{MPa}, 3.21 \mathrm{MPa}$, and $6.97 \mathrm{MPa}$ for compression strength, flexural strength, splitting tensile strength respectively.
\end{abstract}




\section{Introduction}

The use of high-strength Lightweight concrete (HSLWAC) can reduce the self-weight of structures and cross-sectional areas of structural elements. Both can increase the effective usable space for high-rise buildings and increase the span length for bridges [1]. The requirement for structural high strength lightweight aggregate concrete (HSLWAC) in many contemporary construction is increasing, owing to the benefit of higher strength/weight ratio, better capacity of tensile strain, minimum coefficient of thermal expansion because of the voids existing in the lightweight aggregates (L.W.A) and minimum density that is suitable for a decrease of load-bearing elements and the foundation size [2]. The lightweight high strength concrete has densities from 1000 to 2000 $\mathrm{kg} / \mathrm{m}^{3}$ and compressive strength more than $40 \mathrm{MPa}$ [3]. Lightweight aggregates are normally available (volcanic cinders, pumice, diatomite, etc.) or unnaturally made (expanded shale, PFA, perlite, slate, etc.) [4].

(HSLWAC) is considered as a relatively brittle material as the concrete is strong under compression and weak under tension or flexure. Carbon fibers are inert, medically safe, chemically stable, low in density, and their strength-to-density ratio is one of the highest among all fiber types. Carbon fiber has a very high tensile strength (2110 to $2815 \mathrm{~N} / \mathrm{mm}^{2}$ ) and young's modulus. Patodi, and Rarhod, have concluded that, cement composites made with carbon fiber, as reinforcement will have very high modulus of elasticity and flexural strength [2].

\section{Literature Review}

There are many studies have dealt with improved (HSLWAC) characteristics:

Abdul kader Ismail A. et al. in (2013) [7]. Studied the mechanical properties of lightweight aggregate concrete (LWAC) using chopped carbon fibers $5 \mathrm{~mm}$ length, $10 \mu \mathrm{m}$ diameter with different ratios of volume $(0.5 \%, 1 \%$, and $1.5 \%)$ results showed that the addition of carbon fiber increases the compressive strength is about $30 \%$, splitting tensile strength about $58 \%$ and flexural strength about $35 \%$.

Xiang Shu et al. in (2014) [6] carried out to investigate the effects of carbon fiber with different sizes on the mechanical properties of Portland cement mortar. The laboratory test results show that the hybrid fiber mix exhibited superior tensile performance to the microfiber mix.

Wasan Ismail Khalil, et al. in (2015) [7] studied some properties of high strength lightweight aggregate concrete (HSLWAC) reinforced with mono and hybrid fibers in different dimensions and types. High strength porcelinite lightweight aggregate concrete mix. The results shown that mono and hybrid fiber reinforced HSLWAC specimens show significant increase in splitting tensile strength and flexural strength in comparison with plain HSLWAC specimen.

Akar Abdulrazaqet al. in (2011) [8]. Studied the influence of high performance carbon fiber concrete using superplasticizer and condensed silica fume reinforced with different volume fractions $(0 \%$, $0.2 \%, 0.3 \%, 0.4 \%$ and $0.5 \%$ ) of carbon fibers the results show that the addition of carbon fibers improves the mechanical properties of high performance concrete the addition of carbon fibers causes a slight increase in compressive strength and modulus of elasticity of high performance concrete when the fiber volume fraction increases, while the splitting tensile and flexural strengths shows a significant increase relative to the reference high performance concrete (without fiber). The percentage increase in splitting tensile and flexural strengths for high performance concrete with fiber volume fraction $0.5 \%$ at 28 days is about $45 \%$ and $46 \%$ respectively.

\section{Materials}

\section{Cement}

Type I, ordinary Portland cement used in this study from Al- Douh refectory. Test results shown the cement identified with Iraqi specifications No. $5 / 1984$ [9]. The properties of cement shown in the table (1) and (2).

Table (1). Chemical properties of cement

\begin{tabular}{lll}
\hline $\begin{array}{c}\text { Oxide } \\
\text { Percentage }\end{array}$ & Cement & $\begin{array}{l}\text { Limit of Iraqi Spec. } \\
\text { No.5/1984 }\end{array}$ \\
\hline $\mathrm{CaO}$ & 63.2 & - \\
$\mathrm{SiO} 2$ & 18.9 & - \\
$\mathrm{Al} 2 \mathrm{O} 3$ & 3.8 & - \\
$\mathrm{Fe} 2 \mathrm{O} 3$ & 4.6 & - \\
$\mathrm{SO} 3$ & 1.5 & $\leq 2.5$ \\
$\mathrm{Mg} \mathrm{O}$ & 1.7 & 5.0 \\
L.O.I & 1.9 & 4.0 \\
L.S.F & 0.9 & $0.66-1.02$ \\
I.R & 0.4 & $\leq 1.5$ \\
\hline
\end{tabular}

Table (2). Physical properties of cement

\begin{tabular}{|c|c|c|}
\hline $\begin{array}{l}\text { Physical } \\
\text { Properties }\end{array}$ & $\begin{array}{l}\text { Test } \\
\text { results }\end{array}$ & $\begin{array}{l}\text { Limit of } \\
\text { Iraqi Spec. } \\
\text { No.5/1984 }\end{array}$ \\
\hline Initial setting time (vicat) & $65 \mathrm{~min}$. & $\geq 45 \mathrm{~min}$. \\
\hline Final setting time (vicat) & $170 \mathrm{~min}$. & $\leq 375$ \\
\hline $\begin{array}{l}\text { Compressive strength of } \\
\text { mortar (MPa) 3-days }\end{array}$ & 19.0 & $\geq 15$ \\
\hline $\begin{array}{l}\text { Compressive strength of } \\
\text { mortar (MPa) 7-days }\end{array}$ & 30.5 & $\geq 21$ \\
\hline Specific gravity & 3.1 & - \\
\hline Specific surface & 3000 & - \\
\hline
\end{tabular}

\section{Aggregate.}

\subsection{Coarse Aggregate.}

Porcelinite stone was used as coarse aggregate. The quarry of this stone is located in Rutba at the western desert in Anbar. It was received in medium 
lumps from the State Company of Geological Survey and Mining. The physical, chemical and mineral analysis tests were done by the State Company of Geological Survey and Mining (SCGSM). The stone was crushed by crushing machine. The maximum aggregate size was 12.5 $\mathrm{mm}$. Porcelinite was graduated to the grading which was presented in table (3). Due to the porcelinite cellular structure, lightweight aggregate (LWA) absorbs more water than normal weight aggregate. In order to avoid the continuous absorption of porcelinite LWA which caused rapid slump loss, the aggregate was washed with water for sufficient time to attain saturation. Then, the water was dripped off and the aggregate spreads inside the laboratory for suitable time to bring the aggregate particles to saturated surface dry condition ( SSD), which is recommended by ACI committee 211[9] respectively.

Table (3): Grading of Porcelinite Aggregate.

\begin{tabular}{ccc}
\hline $\begin{array}{c}\text { Sieve Size } \\
(\mathrm{mm})\end{array}$ & Passing \% & ASTM C330-04[16] \\
\hline 12.5 & 100 & $90-100$ \\
9.5 & 96 & $85-100$ \\
4.75 & 21 & $10-30$ \\
2.36 & 4 & $0-10$ \\
1.8 & 2 & $0-5$ \\
\hline
\end{tabular}

Table (4): Physical Properties of Fine Aggregate

\begin{tabular}{|c|c|c|c|}
\hline Proprty & Results & $\begin{array}{l}\text { Specificatio } \\
\mathrm{n}\end{array}$ & $\begin{array}{l}\text { Limit of Iraq } \\
\text { Spec. } \\
\text { No45/1984[1 } \\
\text { 7] }\end{array}$ \\
\hline $\begin{array}{l}\text { Bulk } \\
\text { pecific } \\
\text { gravity }\end{array}$ & 2.55 & $\begin{array}{c}\text { ASTM } \\
\text { C128-7[18] }\end{array}$ & \\
\hline $\begin{array}{l}\text { Absorption } \\
\%\end{array}$ & 2.1 & $\begin{array}{l}\text { ASTM } \\
128-97\end{array}$ & \\
\hline $\begin{array}{l}\text { Dry loose } \\
\text { unit weight } \\
(\mathrm{kg} \backslash \mathrm{m} 3)\end{array}$ & 1600 & $\begin{array}{c}\text { ASTM } \\
\text { C29-97[14] }\end{array}$ & \\
\hline $\begin{array}{l}\text { Sulphate } \\
\text { content } \\
\text { SO3 }\end{array}$ & 0.09 & $\begin{array}{c}\text { I.O.S N 45- } \\
\quad 84\end{array}$ & $0.5(\max )$ \\
\hline $\begin{array}{l}\text { Material } \\
\text { finer than } \\
0.075 \mathrm{~mm}\end{array}$ & 0.7 & $\begin{array}{l}\text { BS-882- } \\
1965[19]\end{array}$ & $5.0(\max )$ \\
\hline
\end{tabular}

\subsection{Fine aggregate.}

The grading of fine aggregate are listed in Table (4). A (4.75) mm maximum size of clean sand is used as fine aggregate. and compatible to the requirement of Iraqi specifications No. 45/1984 [10].

Table (5). Sieve analysis of fine aggregate.

\begin{tabular}{ccc}
\hline Sieve size & $\begin{array}{c}\text { Passing ratio } \\
(\%)\end{array}$ & Limit of ASTMC33-03 \\
\hline & & \\
$9.5 \mathrm{~mm}$ & 100.00 & 100 \\
$4.75 \mathrm{~mm}$ & 94.56 & $95-100$ \\
$2.36 \mathrm{~mm}$ & 72.45 & $80-100$ \\
$1.18 \mathrm{~mm}$ & 68.40 & $50-85$ \\
$600 \mu \mathrm{m}$ & 53.32 & $25-60$ \\
$300 \mu \mathrm{m}$ & 16.60 & $5-30$ \\
$150 \mu \mathrm{m}$ & 2.12 & $0-10$ \\
\hline
\end{tabular}

\section{Superplasticizer.}

Superplasticizer is high range water reducing additives, It meet the requirements of super plasticizer according to ASTM-C494 Type B, D and $\mathrm{G}$ [13].Table (6) shows the typical properties of superplasticizer. High range water reducing (HRWRA) added to decrease the water demand of the concrete, when Silica fume added and reducing w/c.

Table 6. Typical properties of superplasticizer

\begin{tabular}{lc}
\hline properties & Specifications \\
\hline Specific gravity & 1.2 \\
Form & Liquid \\
PH & $7-9$ \\
\hline
\end{tabular}

\section{Silica Fume (SF)}

Table (7) shown the properties of silica fume according to ASTM C-1240-05[14], which shown in Fig. (1-b), the silica fume added in a dry state to the cement and thoroughly mixed with it in order to provide a homogenous mixture. Silica fume have a very high water demand.

Table (7) shown the chemical and physical properties of silica fume.

\begin{tabular}{|c|c|c|c|}
\hline $\begin{array}{l}\text { Oxide } \\
\text { composition }\end{array}$ & $\begin{array}{c}\text { Oxide } \\
\text { Content } \%\end{array}$ & $\begin{array}{l}\text { Physical } \\
\text { Properties }\end{array}$ & $\begin{array}{c}\text { ASTM C- } \\
1240 \\
\text { Limitations }\end{array}$ \\
\hline $\mathrm{SiO}_{2}$ & 91.4 & - & $\geq \% 85$ \\
\hline L.O.I & 0.53 & - & $\leq 6.0$ \\
\hline $\mathrm{SO}_{3}$ & 0.13 & - & \\
\hline $\mathrm{MgO}$ & 1.03 & - & - \\
\hline $\mathrm{Na} 2 \mathrm{O}$ & 0.16 & - & - \\
\hline $\begin{array}{l}\text { Percent } \\
\text { retained on }\end{array}$ & & & \\
\hline $\begin{array}{l}45 \mu \mathrm{m}(\text { No. } \\
325) \text { sieve } \\
, \max , \%\end{array}$ & 8 & - & $\leq 10$ \\
\hline $\begin{array}{l}\text { Specific } \\
\text { gravity }\end{array}$ & - & 2.21 & - \\
\hline $\begin{array}{l}\text { Bulk } \\
\text { density }\end{array}$ & - & $310 \mathrm{~kg} / \mathrm{m}^{3}$ & - \\
\hline $\begin{array}{l}\text { Specific } \\
\text { Surface }\end{array}$ & - & $20 \mathrm{~m}^{2} / \mathrm{gm}$. & $\geq 15$ \\
\hline form & - & Amorphous & - \\
\hline
\end{tabular}

\section{Carbon Fiber (C.F.)}

A High execution of carbon fiber used in this study shown in Fig. (1-a). Carbon fiber complied with requirements of ASTM C1116-02 [12].Table (8) indicated the characteristics of carbon fiber High performance high strength chopped carbon fiber brought form waste factory as filaments was used in this investigation. Table (8) indicates the mechanical properties of chopped carbon fiber used in this investigation. 
Table (8): Physical and Technical Properties of carbon Fiber (C.F.)

\begin{tabular}{lc}
\hline Properties & Results \\
\hline Filament Diameter, $\mu \mathrm{m}$ & 8 \\
Bulk Density (min.), g/L & 427 \\
Elongation, \% & 1.53 \\
Tensile Strength, MPa & 1635 \\
Flexural Strength, MPa & 260 \\
\hline
\end{tabular}

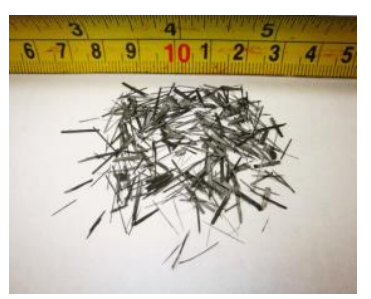

(a)

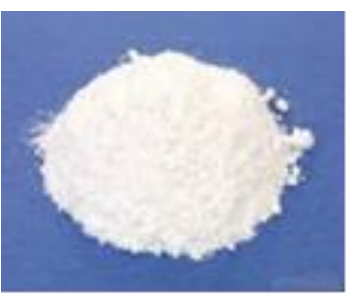

(b)
Figure (1): (a) Carbon fibers (b) Silica fume. Mix Proportions

The reference mixture is made by (ACI 211.2-02) [16], after several trial mixes were carried out in order to select the optimum dosage of (HRWRA) and silica fume. The (HRWRA) has been used to reduce the $\mathrm{w} / \mathrm{c}$ ratio and maintain the same workability of the reference mix $(100 \pm 5 \mathrm{~mm}$ slump according to ASTM C-143) which causes increase in the strength of LWAC. The selected HSLWAC has mix proportion of 1:1.35:1.87 (cement: sand: aggregate.) by weight with cement content 520 $\mathrm{kg} / \mathrm{m}^{3}$ and w/c ratio of 0.28 , HRWRA 2.5 liter per $100 \mathrm{~kg}$ and $5 \% \mathrm{SF}$ as replacement by weight of cement. The compressive strength and oven dry density of the selected mix are $62.3 \mathrm{~N} / \mathrm{mm}^{2}$ and $1955 \mathrm{~kg} / \mathrm{m}^{3}$ respectively at 28 day age. The carbon fiber is used in varying length $5 \mathrm{~mm}, 10 \mathrm{~mm}$, and $20 \mathrm{~mm}$ with $(0.25 \%, 0.5 \%, 1.0 \%, 1.5 \%$, and $2 \%)$ in volume fraction. Table (8) shows the proportions of mixes of (HSLWAC) with coarse aggregate. for all mixtures the aggregates was used in saturated surface dry case (S.S.D.) Specific surface area of (S.F.) is greater than the cement, therefore the concrete performance is reduced fundamentally and more water is needed to fix it, because the concrete Performance should not be changed; the amount of superplasticizer is increased. [17].

Casting and Curing of (HSLWAC).

The samples cast in three layers by rodding 25 times with applying a vibration for (10) seconds. After mixing, the specimens disposed of the molds and maintained in the water until they will arrive the test age of (7) and (28) days when they are ready to do the experimental tests.

\section{Concrete testing.}

(HSLWAC) specimens prepared at general according to ASTM C192-02.[21].For each mix, six $(150 \mathrm{~mm})$ standard cubic steel molds used for casting specimens and for Compression strength in (7) and (28) days in agreement with ASTM C39-98 [22], the splitting tensile strength used two molds of
(100X200) mm cylindrical concrete samples measured conformity to the ASTM C 496- 86[23], two $(100 \times 100 X 400 \mathrm{~mm})$ prisms for flexural strength at (28) day, correspond with ASTM(C29302).[24].

Table 9: Mix Proportion for cubic meter of concrete.

\begin{tabular}{lc}
\hline \multicolumn{1}{c}{ Ingredients } & $\begin{array}{c}\text { Quantity } \\
\left(\mathrm{kg} / \mathrm{m}^{3}\right)\end{array}$ \\
\hline Cement content & 520 \\
Fine aggregate & 700 \\
Coarse aggregate & 995 \\
water & 146 \\
Superplasticizer & 11.3 \\
Silica fume & 5 \\
\hline
\end{tabular}

Table 10: Mix Designation for fiber content in volume fraction.

\begin{tabular}{cccc}
\hline $\begin{array}{l}\text { Fiber Volume } \\
\text { friction }(\%)\end{array}$ & \multicolumn{3}{c}{ Length of carbon fiber $(\mathrm{mm})$} \\
\hline 0 & 5 & 10 & 20 \\
\hline 0.25 & $\mathrm{CF} 0$ & $\mathrm{CF} 0$ & $\mathrm{CF} 0$ \\
0.5 & $\mathrm{M} 1$ & $\mathrm{~N} 1$ & $\mathrm{~L} 1$ \\
1.0 & $\mathrm{M} 3$ & $\mathrm{~N} 2$ & $\mathrm{~L} 2$ \\
1.5 & $\mathrm{M} 4$ & $\mathrm{~N} 4$ & $\mathrm{~L} 3$ \\
2.0 & $\mathrm{M} 5$ & $\mathrm{~N} 5$ & $\mathrm{~L} 4$ \\
\hline
\end{tabular}

\section{Results and Discussion \\ Workability (slump)}

In this study, the quantity of water and SP were kept constant for all mixes in order to evaluate the effects of different CF fibers on the workability of OPC. Slump tests were carried out to determine the consistency of fresh concrete. The use of carbon fibers is well known to affect the workability and flowability of plain concrete intrinsically [26]. From Fig. 2, it can be seen that the slump value of fresh (HSLWAC) decreases due to an increase in $\mathrm{CF}$ fiber volume fraction. The addition of carbon fibres from $0.25 \%$ to $2 \%$ of volume fraction for length $5 \mathrm{~mm}$ reduces the range of slump values by approximately $6.3 \%-36.8 \%$. The results also indicate that, the carbon fibers of long length produced a lower slump, for length $10 \mathrm{~mm}$ the reduction in slump values was $9.5 \%-38.9 \%$ and length $25 \mathrm{~mm}$ the reduction in slump values was 15.8\%-40\%. Mehta and Montero [26] reported that a slump value for structural lightweight concrete in the range of $50-75 \mathrm{~mm}$ is comparable to an equivalent value of slump of 100-125 mm for normal concrete. This phenomenon might be attributed to the long length of fibres have higher effective surface area for the cement paste to wrap around due to the high fiber content and long of fibres, which in turn, increases the viscosity of the development of a fiber-matrix bond compared to shorter fibres. The bond increases the viscosity which restrains the mixture from segregation and flow. The fibres have the tendency to absorb admixture [27]. 
Table 11: Fresh and hardened properties of (HSLWAC) with carbon fibers

\begin{tabular}{cccccccc}
\hline $\begin{array}{c}\text { Length of } \\
\text { Carbon } \\
\begin{array}{c}\text { Fibers } \\
(\mathrm{mm})\end{array}\end{array}$ & $\begin{array}{c}\text { \% of } \\
\text { Carbon }\end{array}$ & $\begin{array}{c}\text { Slump } \\
(\mathrm{mm})\end{array}$ & $\begin{array}{c}\text { Compressive } \\
\text { Ftrength } \\
\text { MPa }\end{array}$ & $\begin{array}{c}\text { Compressive } \\
\text { Strength } \\
\text { MPa } \\
\text {-days }\end{array}$ & $\begin{array}{c}\text { Split } \\
\text { Tensile } \\
\text { Strength } \\
\text { MPa }\end{array}$ & $\begin{array}{c}\text { Flexural } \\
\text { Strength } \\
\text { MPa }\end{array}$ & $\begin{array}{c}\text { Modulus } \\
\text { of } \\
\text { Elasticity } \\
\text { MPa }\end{array}$ \\
\hline & 0 & & & & & & \\
& 05 & 35.14 & 41.34 & 2.12 & 3.74 & 27722 \\
5 & 0.25 & 89 & 35.43 & 41.68 & 2.33 & 4.54 & 27903 \\
& 0.5 & 81 & 35.83 & 42.15 & 2.48 & 4.88 & 28098 \\
& 1.0 & 73 & 36.19 & 42.58 & 2.69 & 5.25 & 29256 \\
& 1.5 & 66 & 36.75 & 43.23 & 3.01 & 5.89 & 31510 \\
& 2.0 & 60 & 36.91 & 43.42 & 3.15 & 6.01 & 32617 \\
& 0 & 95 & 35.14 & 41.34 & 2.12 & 3.74 & 27722 \\
10 & 0.25 & 86 & 35.57 & 41.85 & 2.45 & 4.68 & 28120 \\
& 0.5 & 78 & 36.11 & 42.48 & 2.88 & 5.34 & 28311 \\
& 1.0 & 70 & 36.52 & 42.97 & 3.01 & 5.48 & 33709 \\
& 1.5 & 64 & 37.10 & 43.65 & 3.07 & 6.32 & 36952 \\
& 2.0 & 58 & 37.60 & 44.23 & 3.18 & 6.57 & 39400 \\
& 0 & 95 & 35.14 & 41.34 & 2.12 & 3.74 & 27722 \\
& 0.25 & 80 & 35.90 & 42.23 & 2.56 & 4.95 & 28406 \\
& 0.5 & 72 & 36.70 & 43.18 & 2.78 & 5.74 & 33792 \\
& 1.0 & 65 & 37.58 & 44.21 & 3.02 & 5.89 & 36433 \\
& 1.5 & 59 & 38.15 & 44.88 & 3.12 & 6.65 & 39800 \\
& 2.0 & 57 & 38.62 & 45.44 & 3.21 & 6.97 & 40413 \\
\hline
\end{tabular}

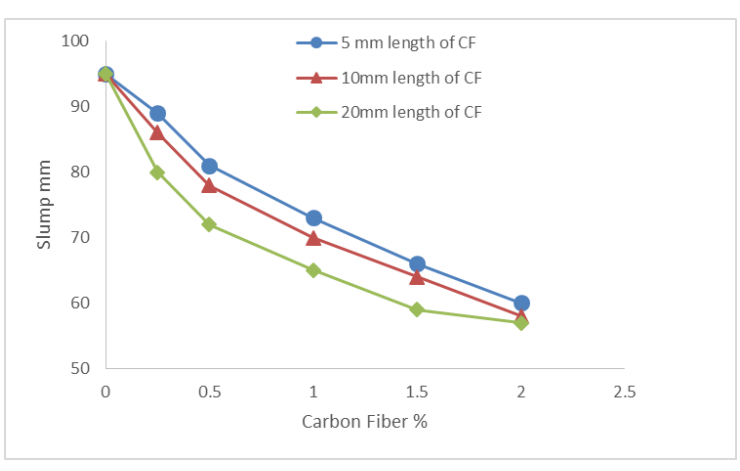

Figure (2) slump $\mathrm{mm}$ of all mixes with deferent length of carbon fibers.

Results of Compression strength.

As it is seen in table (11) presents the Compression strength test results and figure (3) at (7) and (28) day, it can be found that (HSLWAC) made with Carbon Fibers (C.F.) in addition silica fume had more Compression strength than control mix, the raise in the Compression strength at 28 days was more than their conformable Compression strength at (7) days due to the condensation of product of hydration process with silica fume about the
Carbon fiber and loss the transition zone porous and further improves the mechanical properties of the concrete [29]. Figure 3 presents the variation of compressive strength with carbon fiber content, it is observed that, compressive strength increases with fiber length and fiber content. The increase in strength is more predominant for $20 \mathrm{~mm}$ length fibers. For the given fiber content, $20 \mathrm{~mm}$ length fibers show higher compressive strength compare to $5 \mathrm{~mm}$ and $10 \mathrm{~mm}$ length fibers. At $2 \%$ fiber content $20 \mathrm{~mm}$ length fiber shows $10 \%$ increase in compressive strength whereas the increase is by compressive strength whereas the increase is by $5.03 \%$ and $7 \%$ for $5 \mathrm{~mm}$ and $10 \mathrm{~mm}$ length of fibers respectively, compared with the strength of high strength concrete with $0 \%$ carbon fiber. This condition can be attributed to the improvement in the mechanical bond strength when the fibers both have the ability to delay the micro- crack formation and arrest their propagation afterward up to a certain extent $[14,15]$. The maximum Compression strength of (HSLWAC) was (45.44) $\mathrm{MPa}$ at (28) days of age founded in the mix (L5) with $2 \%$ of carbon fibers. 


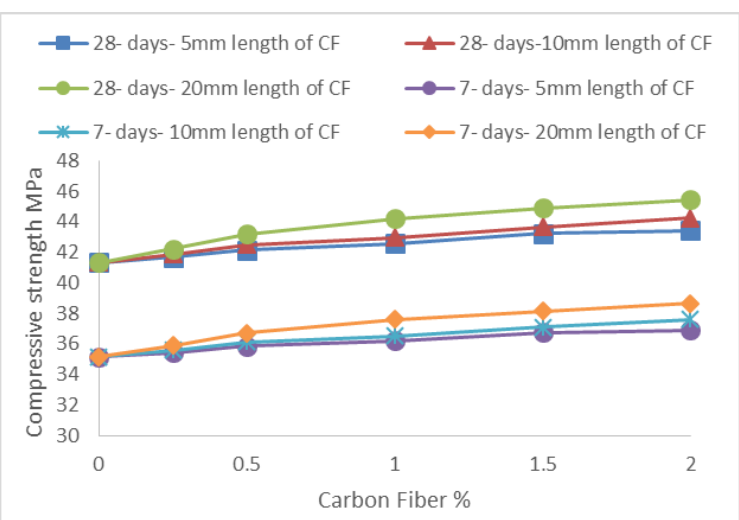

Figure (3) compressive strength with carbon fibers percentage at (7) and (28) days for different lengths.

\section{Splitting Tensile Strength}

The test results on split tensile strength of (HSLWAC) with carbon fibers is shown in Table 11 and plotted in Fig 4. It is observed from the Fig. 4, that the split tensile strength shows increase in strength with increasing fiber content relative to the plain specimens (without fiber). The percentage increase in splitting tensile strength for $5 \mathrm{~mm}$ length HSLWAC mixes (M1, M2, M3, M4, and M5) containing of volume fraction $0.25 \%, 0.5 \%, 1 \%$, $1.5 \%$ and $2 \%$ carbon fiber is $10 \%, 17 \%, 26.9 \%$, $41.5 \%$ and $48.6 \%$ respectively relative to the CF0 specimens. This is attributed to the mechanism of fibers in arresting crack progression and the improvement of bond between fibers and matrix due to the extra dense calcium silicate hydrate gel obtained from silica fume addition [18].

Also Fig. (4) indicate that the $20 \mathrm{~mm}$ length fibers show higher split tensile strength compare to 10 $\mathrm{mm}$ length fibers. The percentage increase in splitting tensile strength for HSLWAC mixes containing $20 \mathrm{~mm}$ fiber type (L1, L2, L3, L4, and L5) with volume fraction $0.5 \%, 1 \%$ and $0.25 \%$ carbon fiber is $4.5 \%, 3.6 \%, 0.3 \%, 1.6 \%$ and $0.9 \%$ respectively relative to $10 \mathrm{~mm}$ length fibers. This is attributed to the mechanism of fibers in arresting crack progression and the improvement of bond between fibers and matrix due to the extra dense calcium silicate hydrate gel obtained from silica fume addition [18].

Splitting failure characteristics of HSLWAC completely change with presents of fibers. Non fibrous concrete specimens suddenly failed in a brittle manner and separated into two parts; all samples of mono and hybrid fibrous HSLWAC consist of two parts still connected by fibers bridging the major crack. A reduction in crack width was observed in hybrid fibers HSLWAC which significantly contributed to the reduction in overall crack area.

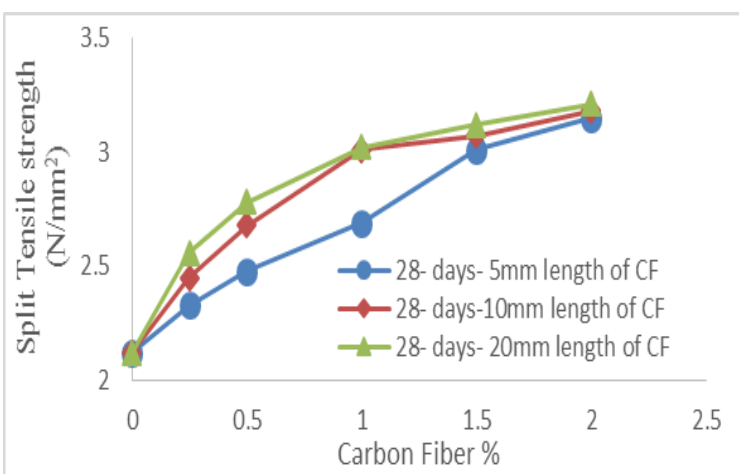

Figure. (4) Splitting tensile strength with carbon fibers percentage at (28) days with different lengths.

\section{Flexural Strength}

Flexural strength test results are given in Table (11) and plotted in Fig 5, show significant improvement in flexural strength with the addition of carbon fibers. The increase in flexural strength is more sensitive with fiber content compared to compressive and split tensile strength, for a given fiber length. Maximum increase of $86.4 \%$ in flexural strength is observed at mix (M5) content for $5 \mathrm{~mm}$ length fiber compared to a flexural strength of high strength concrete with $0 \%$ fibers.

The comparison between flexural strength values for HSLWAC specimens of $20 \mathrm{~mm}$ length mixes (L1, L2, L3, L4, and L5) and $10 \mathrm{~mm}$ length mix specimens (N1, N2, N3, N4, and N5) shows that the percentage of increase in flexural strength is $6.88 \%$, $5.8 \%, 11.7 \%, 7.5 \%, 5.2 \%$ and $6.1 \%$ respectively. This is because carbon fibers are strong and stiff and they can blunt and arrest microcracks before they coalesce into macro cracks leading to fracture [23].Plain HSLWAC exhibited brittle failure under flexural with the specimen being separated into two pieces. Fibrous high strength lightweight aggregate concrete mix with carbon fiber content $0.25 \%$ shows the same behavior. This is due to the lower elastic modulus of the carbon fiber.

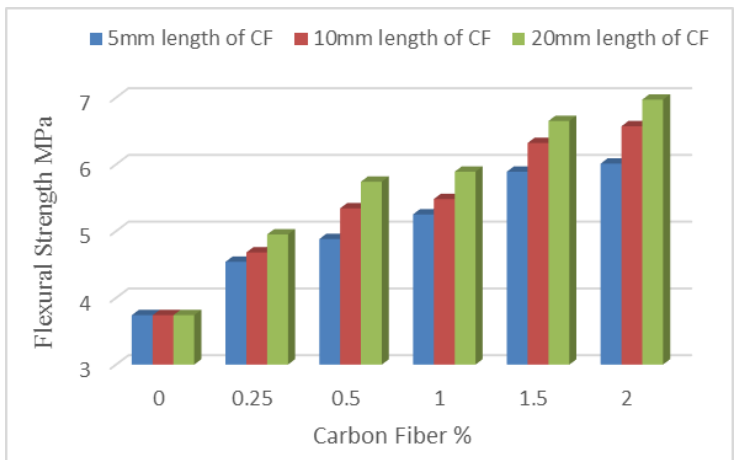

Figure. (5) Flexural strength with carbon fibers percentage for different lengths.

Modulus of elasticity

Test results for Modulus of elasticity indicate that in table (11) and figure (6). The addition of carbon fibers show branching raise in the elasticity. Like to 
strength properties the modulus of elasticity also shows increased values at higher fiber content. For example at $5 \mathrm{~mm}$ length the modulus of elasticity shows increase with increasing fiber content relative to the plain specimens (without fiber). The percentage increase in modulus of elasticity HSLWAC mixes (M1, M2, M3, M4, and M5) containing of volume fraction form $0.25 \%$ to $2 \%$ carbon fiber is in the range $0.7 \%-17.7 \%$ respectively relative to the $(\mathrm{CF} 0)$ reference mix. Also the increasing length of carbon fibers shown raises the modulus of elasticity as in the other strength factors.

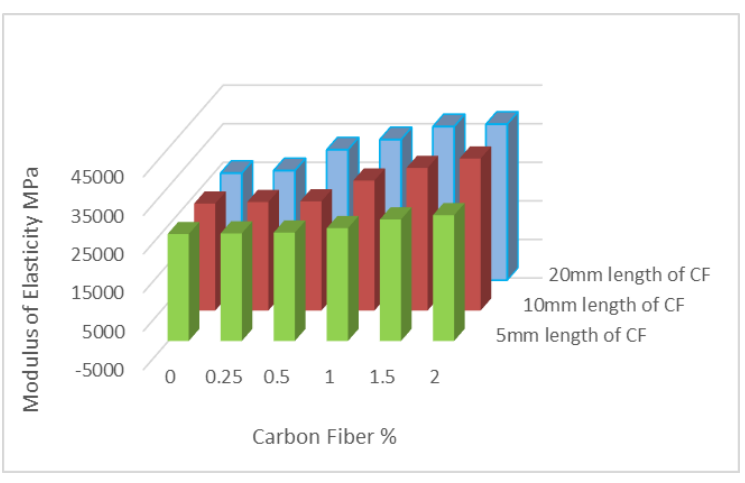

Figure (6). Modulus of elasticity for all mixes.

\section{CONCLUSIONS}

The control (HSLWAC) has a density of (1835) $\mathrm{kg} / \mathrm{m}^{3}$, and the voids content was reducing with increasing the percentage of silica fume, the lowest density of (1746.72) kg/m $\mathrm{m}^{3}$ was from the mix (PC5) at 28-days. It permeability coefficient (K) and voids content was (0.324) $\mathrm{cm} / \mathrm{s}$, and (30.21\%) respectively.

(1) Carbon fibres reduce the slump value of concrete. The reduction in slump value is within the range of $11 \%-64 \%$ for different length of carbon fibres. However.

(2) The compressive strength of (HSLWAC) increases with an increase in carbon fibres content. Plain (HSLWAC) concrete has a 28-day compressive strength of $41.34 \mathrm{MPa}$, and this value increases to $43.42 \mathrm{MPa}$ when the concrete is reinforced with $2 \%$ volume fraction for mix (M5) of $5 \mathrm{~mm}$ length carbon fibers, also the compressive strength of (HSLWAC) increases with longer the length of carbon fibres to $10 \mathrm{~mm}$ and $20 \mathrm{~mm}$ were $45.44 \mathrm{MPa}$ and $44.23 \mathrm{MPa}$ for mixes (N5) and (L5) of $2 \%$ volume fraction.

(3) The excess the content of carbon fibers in HSLWAC with $5 \mathrm{~mm}$ length significantly improves the splitting tensile strength of mix (M5) reinforced specimens was $48.6 \%$ relative to the reference specimens. HSLWAC specimens show significant increase in splitting tensile strength with increasing content. The percentage increase in splitting tensile strength for HSLWAC mixes containing $20 \mathrm{~mm}$ fiber type (L1, L2, L3, L4, and L5) with volume fraction $0.5 \%, 1 \%$ and $0.25 \%$ carbon fiber is $4.5 \%$, $3.6 \%, 0.3 \%, 1.6 \%$ and $0.9 \%$ respectively relative to $10 \mathrm{~mm}$ length fibers.

(4) The effect of incorporating of carbon fibres in improving the flexural strength with increased content of carbon fibers is more pronounced compared to its effect on splitting tensile strength. The higher percentage increase in flexural strength for (L5) mix was $6.97 \mathrm{MPa}$ compared with reference concrete mix $(\mathrm{CF} 0)$.

(5) For Modulus of elasticity indicate that the addition of carbon fibers show marginal increase in the elasticity. Similar to strength properties the modulus of elasticity also shows increased values at higher fiber length and fiber content.

\section{References}

1. Kılıç, A., Atiş, C.D., Yaşar, E. and Özcan, F., 2003. High-strength lightweight concrete made with scoria aggregate containing mineral admixtures. Cement and Concrete Research, 33(10), pp.1595-1599.

2. Chia, K.S. and Zhang, M.H., 2002. Water permeability and chloride penetrability of highstrength lightweight aggregate concrete. Cement and Concrete Research, 32(4), pp.639-645.

3. Committee, A.C.I., 2009. 213.(nd). Guide for Structural Lightweight-Aggregate Concrete (ACI 213R-03). ACI Manual of Concrete Practice, pp.120.

4. Domagała, L., 2015. The effect of lightweight aggregate water absorption on the reduction of water-cement ratio in fresh concrete. Procedia Engineering, 108, pp.206-213.

5. Abdul kader Ismail A. L., 2013. The effect of lightweight aggregate water absorption on the reduction of water-cement ratio in fresh concrete. Procedia Engineering, 108, pp.206-213.

6 Yang, X., Wei, J., Nanni, A. and Dharani, L.R., 2004. Shape effect on the performance of carbon fiber reinforced polymer wraps. Journal of Composites for Construction, 8(5), pp.444-451.

7. Khalil, W.I. and Mozan, S.A.A.J., 2015. Some Properties of Hybrid Fibers High Strength Lightweight Aggregate Concrete. Engineering and Technology Journal, 33(4 Part (A) Engineering), pp.815-829.

8. Khalil, W.I. and Abdulrazaq, A., 2011. Mechanical Properties of High Performance Carbon Fiber Concrete. Engineering and Technology Journal, 29(5), pp.906-924.

9. Iraqi specification No. 5 (1984); "specification for Portland Cement". 
10. ASTM C 330-04. (2004). Standard Specification for Lightweight Aggregates for Structural Concrete.

11. ASTM, C., 2001. 128. Standard test method for specific gravity and absorption.

12. ASTM Specf.C33-01. (2001). Standard Specification for Aggregates, Annual Book of ASTM Standards, PP1-8.

13. ASTM-C494 -02 "Standard Specification for Chemical Admixtures for Concrete" Annual Book of ASTM Standards, 2002.

14. ASTM C1240-05"Standard Specification for Use of Silica Fume as a Mineral Admixture in Hydraulic-Cement Concrete, Mortar, and Grout" Vol.04.0.2,pp.1-7

15. ASTM C1116-02 "Standard Specification for Fiber-Reinforced Concrete and Shotcrete" Annual Book of ASTM Standards, 2002

16. ACI Committee report 211.2-98. (1998). Standard Practice for Selecting Proportions for Structural Lightweight Concrete. American Concrete Institute, Farmington Hills. MI, United States.

17. ASTM, C., 1996. 143. Standard test method for slump of hydraulic cement concrete, ASTM International, West Conshohocken, PA, USA, 4. 18. Rachel J.D. "chemical and physical effects of silica fume on the mechanical behavior of concrete" ACI materials journal, Nov.-Dec. 1989, P.P. 609613

19. ASTM C192-02" Standard Practic for Making Curing Concrete Test Specimens in the Laboratory "Annual Book of ASTM Standards, Vol 04.02.

20. ASTM (39) -98). "Standard test method for Compression strength of cylindrical concrete specimens." Annual Book of ASTM Standards, Vol. 04.02

21. ASTM C 496- 86 "Standard Test Method for Splitting Tensile Strength of Cylindrical Concrete Specimens" Annual Book of ASTM Standards,Vol.04-02,1989,pp.259-262.

22.Standard, A.S.T.M., 2010. C469/C469M,(2010). Standard test method for static modulus of elasticity and Piosson's ratio of concrete in compression.

23. ASTMC293 - 02 "Standard Test Method for Flexural Strength of Concrete (Using Simple Beam with Center-Point Loading)" Annual Book of ASTM Standards, Vol.04-02

24. Shehata M. "Optimizing the strength and permeability of (HSLWAC)". Ryerson University, Department of Civil Engineering; 2010.
25. Montero, M.A. and Mehta, M., 1983. Pain in the anterior abdominal wall. Treatment by selective destruction of the nerve by heat. Revista espanola de anestesiologia y reanimacion, 30(1), p.13.

26. M. Mazloom A.A. Ramezanianpour, J.J. Brooks "Effect of silica fume on mechanical properties of high-strength concrete" Cement \& Concrete Composites 26 (2004) 347-357.

27. .Elsaid, A.; Dawood, M.; Seracino, R.; and Bobko, C. (2011). Mechanical properties of kenaf fibre reinforced concrete, Construction and Building.Materias, 25(4), 1991-2001.

28. Mohamed R. A. S. "Effect of carbons fibers on the mechanical properties of normal concrete" Journal of Engineering Sciences, Assiut University, Vol. 34, No. 4, pp. 1049-1059, July 2006.

29. Mohit Dwivedi,Shobhit Mishra,Vishal Singh 2014 "Effect of Polypropylene Fibres on Flexural Strength of M30 Grade Concrete" IOSR Journal of Mechanical and Civil Engineering e-ISSN: 22781684,p-ISSN: 2320-334X, Volume 11, Issue 4 Ver. II ,PP 93-97.

30. Jing Yang, Guoliang Jiang2003. "Experimental study on properties of pervious concrete pavement materials" Cement and Concrete Research 33 p.p 381-386. 